\title{
Effect of Differential Nutrient Levels on the Performance of Paddy Hybrid Variety during Kharif Season
}

\author{
Poulomi Nandy ${ }^{1 *}$, Subhendu Bikash Goswami ${ }^{1}$ and Sanjib Kumar Das ${ }^{2}$ \\ ${ }^{1}$ Department of Agronomy, Faculty of Agriculture, Bidhan Chandra Krishi Viswavidyalaya, \\ Mohanpur, Nadia, 741252, India \\ ${ }^{2}$ All India Co-ordinate Research Project, Directorate of Research, Bidhan Chandra Krishi \\ Viswavidyalaya, Kalyani, Nadia, 741235, India \\ *Corresponding author
}

\begin{abstract}
A B S T R A C T
The field experiment was conducted during the kharif season of 2015 at Teaching Farm, Mondouri in New Alluvial Zone (NAZ) under Bidhan Chandra Krishi Viswavidyalaya, Nadia to study the 'Effect of differential nutrient levels on the performance of paddy hybrid variety during kharif season'. The experiment was laid out in split plot design with six treatment combinations consisting of two cultivars, three levels of fertility in three replicates. The cultivars were PAC 8744 (hybrid) and IET $4786(\mathrm{HYV})$ tested with different levels of NPK nutrient supply as $60: 30: 30,80: 40: 40$, 100: $50: 50 \mathrm{~kg} \mathrm{~N}, \mathrm{P}_{2} \mathrm{O}_{5}$ and $\mathrm{K}_{2} \mathrm{O}$ ha ${ }^{-1}$ with a plant spacing of $20 \mathrm{~cm} \times 15 \mathrm{~cm}$. The results revealed that hybrid rice variety PAC 8744 performed well as compared to high yielding variety IET 4786 in respect of different crop growth and yield attributes. The varietal effect was significantly noted in crop growth in terms of plant height, tillering and dry matter production at $60 \mathrm{DAT}$ and at harvest. Among the yield components, the effective tillers per square meter, number of filled grains per panicle, numbers of chaffy grains per panicle and test weight were significantly influenced by the variety and nutrient management. In hybrid PAC 8744 , number of panicle per $\mathrm{m}^{2}$ was 472 which were $41.3 \%$ more than IET 4786. The highest tiller production was noted in $\mathrm{F}_{3}-100: 50: 50 \mathrm{~kg} \mathrm{~N}, \mathrm{P}_{2} \mathrm{O}_{5}$ and $\mathrm{K}_{2} \mathrm{O} \mathrm{ha}^{-1}$. Both grain and straw yield were significantly influenced by variety and nutrient level. The highest grain and straw yield of 6.05 and $9.18 \mathrm{t} \mathrm{ha}^{-1}$ were found in PAC 8744 with NPK nutrient level of @ 100:50:50 kg ha ${ }^{-1}$ respectively. The yield advantage of PAC 8744 was $78.61 \%$ higher over IET 4786 during kharif season of 2015. In a similar way, the experimental result revealed that the hybrid variety PAC 8744 showed higher benefit-cost ratio of 2.17 with maximum response to the highest level of nutrient management of $\mathrm{N}, \mathrm{P}_{2} \mathrm{O}_{5}$ and $\mathrm{K}_{2} \mathrm{O} @ 100: 50: 50 \mathrm{~kg} \mathrm{ha}^{-1}$. It was, therefore, advantageous to grow hybrid rice cultivar PAC 8744 with the fertilizer dose of 100:50: $50 \mathrm{~kg} \mathrm{~N}$, $\mathrm{P}_{2} \mathrm{O}_{5}, \mathrm{~K}_{2} \mathrm{O}$ ha ${ }^{-1}$ during kharif season so as to obtain higher grain yield over the best check IET 4786 .
\end{abstract}

\section{Keywords}

Hybrid Rice,

Nutrient management, Crop growth, Yield advantage

\section{Article Info}

Accepted:

10 March 2020

Available Online:

10 April 2020

\section{Introduction}

Rice is the staple food for eastern India as well as for more than half of the world's population. It influences the economics and livelihood of several billion people. Medium and low lands are predominant in this part of the country where farmers have no other option but to go for rice cultivation. Yield stagnation and yield plateauing due to aberrant climatic condition with high yielding rice varieties is one of the major constraints to achieve future need for rice production. In West Bengal, the expected demand for rice by 
$2020 \mathrm{AD}$ is around 17.6 million tonnes, which is nearly 16 percent more than that of present rice production of 14.9 million tonnes (Anonymous, 2000). So it is very challenging to increase rice production to attain sufficient quantity of food grains within limited small land holding. Through the cultivation of age old long duration varieties has been replaced by the newly develop high yielding and short duration varieties but still there is a urgent need of extensive adoption of short duration HYVs to achieve our target of rice production in West Bengal in near future. Rice still has great yield potential to be tapped and there are many ways to raise rice yield, such as building of irrigation works, improvement of soil conditions, cultural techniques and breeding of high yielding varieties.

Among them, it seems at present that the most effective and economic way available is to develop hybrid varieties based on the successful experience in China. Balanced application of fertilizer supplies nutrients (from soil and fertilizer) in a well balanced manner and increases the fertilizer use efficiency. Hybrid rice cultivars also responded to judicious application of fertilizer especially $\mathrm{N}, \mathrm{P}$ and $\mathrm{K}$ and yielded higher than HYVs at a particular level (Singh and Virmani, 1990).

They should be evaluated at different levels of $\mathrm{N}, \mathrm{P}$ and $\mathrm{K}$ at various locations during different seasons so as to exploit their maximum vigour. In view of the above facts, the experiment was undertaken to evaluate most suitable nutrient recommendation for hybrid variety in Kharif season in new alluvial soils of West Bengal.

\section{Materials and Methods}

The field experiment was conducted in the year 2015 to study the performance of nutrition on growth and yield at the Teaching
Farm, Mondouri of Bidhan Chandra Krishi Viswavidyalaya, Nadia, West Bengal. The experimental field represented a typical medium land of New Alluvial Zone of Nadia district. The research station is situated at $23.5^{\circ}$ North latitude and $89^{\circ}$ East longitude, with an altitude of $9.75 \mathrm{~m}$ above the mean sea level (MSL). The experimental site comes under sub-tropical humid climate as it is situated just south of tropic of cancer where summer and winter both are short and mild. The experiment was conducted under irrigated shallow, medium land situation. The soil of the experiment field is Gangetic alluvial with sandy loam in texture and belonged to the order of entisol.

The soil was medium in fertility with good drainage facility with $\mathrm{pH}$ of 6.8, Organic carbon (\%) 0.74 , total $\mathrm{N}$ of $230 \mathrm{~kg} \mathrm{ha}^{-1}, \mathrm{P}_{2} \mathrm{O}_{5}$ of $28.50 \mathrm{~kg} \mathrm{ha}^{-1}$ and $\mathrm{K}_{2} \mathrm{O}$ of $178 \mathrm{~kg} \mathrm{ha}^{-1}$. The experiment, replicated thrice, was laid out in split plot design which comprises two factors treatments, first one is variety viz. $\mathrm{V}_{1}$ : PAC 8744 and $\mathrm{V}_{2}$ : IET 4786 in the main plots and another one is fertility levels viz. $\mathrm{F}_{1}: \mathrm{N}, \mathrm{P}_{2} \mathrm{O}_{5}$, $\mathrm{K}_{2} \mathrm{O}$ at 60:30:30 $\mathrm{kg} \mathrm{ha}^{-1}, \mathrm{~F}_{2}: \mathrm{N}, \mathrm{P}_{2} \mathrm{O}_{5}, \mathrm{~K}_{2} \mathrm{O}$ at 80:40:40 kg ha ${ }^{-1}$ and $\mathrm{F}_{3}: \mathrm{N}, \mathrm{P}_{2} \mathrm{O}_{5}, \mathrm{~K}_{2} \mathrm{O}$ at 100:50:50 $\mathrm{kg} \mathrm{ha}^{-1}$ in the sub plots.

The crop was sown on $1^{\text {st }}$ August 2015 in the nursery bed. The crop was transplanted at the age of 25 days at a spacing of $20 \mathrm{~cm}$ rows apart in $42 \mathrm{~m}^{-2}$ plot size with a seed rate of 15 $\mathrm{kg} \mathrm{ha}^{-1}$. Half dose of $\mathrm{N}$ and the entire dose of $\mathrm{P}$ and $\mathrm{K}$ were applied at the time of sowing through urea, single super phosphate and muriate of potash, respectively. Remaining half dose of $\mathrm{N}$ was applied in two equal splits at active tillering and flowering stage.

To maintain aerobic conditions, irrigations were applied whenever soil appears to have developed hair line cracks and excess water of rainfall is removed after 24 hours of occurrences. For all the growth and 
development studies during the crop growth period, five plants were selected randomly and tagged in each plot. Initially the growth parameters were recorded at 30 days after sowing and subsequent observations were taken at an interval of 30 days.

Yield and yield attributing characters was determined using standard procedures. Finally yield was expressed as $\mathrm{t} \mathrm{ha}^{-1}$. The statistical analysis of split plot design with 2 levels of main factors and 3 levels of sub factors was done by standard procedures suggested by Gomez and Gomez (1984).

\section{Results and Discussion}

\section{Growth and developments}

Growth parameters like plant height, tillers/ $\mathrm{m}^{2}$, leaf area index, dry matter accumulation and crop growth rate of rice were positively influenced by varieties and different fertility levels. Plant height was significantly influenced by cultivars used during kharif season. Between the cultivars, PAC 8744 recorded the tallest plant height both at 60 DAT $(105 \mathrm{~cm})$ and at harvest $(111 \mathrm{~cm})$ which were significantly different from IET 4786 at the respective growth stages (Table 1). In general, plant height increase successively with the advancement of the crop age terminating at the maturity due to development of nodes and elongation of the internodes during the vegetative and reproductive stages in almost all the cultivars. Similar result was also found by Yoshida, 1981. Plant height was not significantly influenced by the nutrient levels $\left(\mathrm{F}_{1}\right.$, 60:30:30, $\mathrm{F}_{2}, 80: 40: 40$ and $\mathrm{F}_{3}, 100: 50: 50 \mathrm{~kg}$ $\mathrm{N}, \mathrm{P}_{2} \mathrm{O}_{5}, \mathrm{~K}_{2} \mathrm{O}$ ha $^{-1}$ ) tested in the study (Table 1). With regard to plant height at different stages of observation, no significant variation was noted in the interaction between variety and nutrient management in the investigation (Table 1).
The number of tillers $\mathrm{m}^{-2}$ of rice transplanted in 3rd week of August, was significantly influenced by variety in sandy loam soil of lower Indo-Gangetic plain of West Bengal. The hybrid variety PAC 8744 produced the higher number of tillers $\mathrm{m}^{-2}$ at 30,45 and 60 DAT ranging from 411 to 484 tillers $\mathrm{m}^{-2}$. The number of tillers attained its highest value about one month after transplanting (45 DAT) decreasing thereafter because of death of some of the last tillers to emerge as a result of their failure in completion for light and nutrients (Matsushima, 1957; Ishijuka and Tanaka, 1963). The application of different NPK nutrient doses recorded significant change in number of tillers $\mathrm{m}^{-2}$ of rice irrespective of varieties. In $\mathrm{F}_{3}$ level of nutrient NPK@ $100: 50: 50 \mathrm{~kg} \mathrm{ha}^{-1}$, the highest number of effective tillers $\mathrm{m}^{-2}$ were obtained at 30, 45 and 60 DAT to the tune of 418, 503 and 461 tillers $\mathrm{m}^{-2}$ respectively. The dynamics of variation in tiller number at the respective growth stages (30 DAT, 45 DAT and 60 DAT) increased from the lowest dose of nutrients $\left(\mathrm{F}_{1}, 60: 30: 30 \mathrm{~kg} \mathrm{~N}, \mathrm{P}_{2} \mathrm{O}_{5}, \mathrm{~K}_{2} \mathrm{O}\right.$ ha $^{-}$ $\left.{ }^{1}\right)$ to the highest level of fertility $\left(\mathrm{F}_{3}, 100: 50\right.$ : $50 \mathrm{~kg} \mathrm{~N}, \mathrm{P}_{2} \mathrm{O}_{5}, \mathrm{~K}_{2} \mathrm{O} \mathrm{ha}{ }^{-1}$ ) (Table 1). However, tiller number $\mathrm{m}^{-2}$ at $100: 50: 50 \mathrm{~kg}$ $\mathrm{N}, \mathrm{P}_{2} \mathrm{O}_{5}, \mathrm{~K}_{2} \mathrm{O} \mathrm{ha}^{-1}$ and $80: 40: 40 \mathrm{~kg} \mathrm{~N}$, $\mathrm{P}_{2} \mathrm{O}_{5}, \mathrm{~K}_{2} \mathrm{O}$ ha ${ }^{-1}$ remained at par at 60 DAT.

The growth of leaf area development in terms of leaf area index (LAI) was significantly varied by varieties and nutrient management at all the crop growth stages. Hybrid variety PAC 8744 produced maximum LAI i.e. 2.25, 4.20 and 3.41 at 30 DAT, 60 DAT and at harvest respectively (Table 1). Maximum LAI was observed in both the varieties (Hybrid and high yielding variety) at 60 DAT followed by at the time of harvest. Murthy et al., (1991) and Sitaramaiah et al., (1998) also observed that LAI was maximum in early growth stage than later stages. Significant variation was found on LAI among the different nutrient levels at all the crop growth 
stages. Maximum LAI was produced by applying $\mathrm{F}_{3}$ level of nutrient doses i.e. 100 : 50 : $50 \mathrm{~kg} \mathrm{~N}, \mathrm{P}_{2} \mathrm{O}_{5}, \mathrm{~K}_{2} \mathrm{O}$ ha $^{-1}$ which was statistically at par with the $80: 40: 40 \mathrm{~kg} \mathrm{~N}$, $\mathrm{P}_{2} \mathrm{O}_{5}, \mathrm{~K}_{2} \mathrm{O}$ ha $^{-1}$ dose of nutrient management at 60 DAT (Table 1).

PAC 8744 had significantly accumulated the highest dry matter at all the growth stages as compare to high yielding variety IET 4786. This was also supported by Virmani et al., (1982), Blanco et al., (1990) and Song et al., (1990). Data on dry matter accumulation revealed that there was progressive rise in dry matter accumulation with the advancement of the crop age terminating at the highest value at maturity. Similar observation was recorded by Thakur and Patel, (1999). The greatest rate of increase in dry matter accumulation was occurred during 30 DAT to 60 DAT. The application of different levels of nutrient recorded a change in plant growth in hybrid rice. Dry matter production at 30, 60 DAT and at harvest varied significantly among all doses of nutrient management. However, the treatment receiving $100: 50: 50 \mathrm{~kg} \mathrm{~N}, \mathrm{P}_{2} \mathrm{O}_{5}$, $\mathrm{K}_{2} \mathrm{O}$ ha $^{-1}$ produced significantly highest dry matter than other doses of nutrient management. The treatment $\mathrm{F}_{2}$ and $\mathrm{F}_{3}$ were statistically at par both at 60 DAT and 90 DAT. Maximum dry matter production was achieved during 90 DAT and the ranges were $665.82 \mathrm{~g} \mathrm{~m}^{-2}$ from $\mathrm{F}_{1}$ level of nutrient to $710.92 \mathrm{~g} \mathrm{~m}^{-2}$ from $\mathrm{F}_{3}$ level of nutrient management (Table 1).

Crop growth rate (CGR) of transplanted rice was significantly influenced by variety. The maximum CGR was noted in the hybrid rice variety i.e. PAC 8744 at 30-60 DAT interval $\left(13.5 \mathrm{~g} \mathrm{~m}^{-2}\right.$ day $\left.^{-1}\right)$. Nutrient management did not exert any significant influence on crop growth rate in the investigation (Table 1). Variety $\times$ nutrient management interaction effect on CGR at both the periods $(30-60$ DAT and 60-90 DAT) of study was not significant (Table 1).

\section{Yield and yield attributes}

Fertility levels and varieties significantly influenced all the yield attributes viz. number of effective tillers $\mathrm{m}^{-2}$, number of filled grains panicle $^{-1}, 1000$-grain weight, grain yield and straw yield. Two rice varieties (PAC 8744 and IET 4786) grown in the experiment did not differ among themselves for panicle length (Table 4.2). Panicle length varied significantly due to different levels of nutrient management. Highest $(24.6 \mathrm{~cm})$ data recorded on F3 nutrient level i.e. $100: 50: 50 \mathrm{~kg} \mathrm{~N}$, $\mathrm{P} 2 \mathrm{O} 5, \mathrm{~K} 2 \mathrm{O} \mathrm{ha} \mathrm{ha}^{-1}$ and lowest $(21.78 \mathrm{~cm})$ was obtained from F1 nutrient level i.e. 60 : 30 : $30 \mathrm{~kg} \mathrm{~N}, \mathrm{P} 2 \mathrm{O} 5, \mathrm{~K} 2 \mathrm{O} \mathrm{ha}{ }^{-1}$ (Table 2).

Hybrid rice variety PAC 8744 recorded the higher number of ear bearing tillers of 473 than the IET 4786 (334). Tiller production variation between two variety was about 42.5\%. Data recorded from the experiment revealed that increasing level of nitrogen significantly increased the number of panicle $\mathrm{m}^{-2}$ of transplanted rice during kharif season. Rice grown with nutrient level of $100: 50$ : $50 \mathrm{~kg} \mathrm{~N}, \mathrm{P} 2 \mathrm{O} 5, \mathrm{~K} 2 \mathrm{O} \mathrm{ha}^{-1}$ (F3) resulted in highest number of panicle $\mathrm{m}^{-2}$ (391) being statistically at par with $80: 40: 40 \mathrm{~kg} \mathrm{~N}$, $\mathrm{P} 2 \mathrm{O} 5, \mathrm{~K} 2 \mathrm{O}$ ha $^{-1}$ (F2), but significantly greater over 60 : $30: 30 \mathrm{~kg} \mathrm{~N}, \mathrm{P} 2 \mathrm{O} 5, \mathrm{~K}_{2} \mathrm{O} \mathrm{ha} \mathrm{h}^{-1}$ (F1). Number of tillers $\mathrm{m}^{-2}$ differentiation due to increase of nutrient dose was about $27.36 \%$ from $F_{1}$ to $F_{3}$ levels (Table 2).

The grain filling of rice was significantly influenced by variety. Between the rice varieties tested in the experiment, PAC 8744 produced greater number of filled grains panicle $^{-1}$ (116) over the high yielding variety IET 4786 (73). With regard to nutrient management, number of filled grains panicle ${ }^{-1}$ varied significantly. Highest number of filled grains panicle ${ }^{-1}$ (103) was obtained by applying $100: 50: 50 \mathrm{~kg} \mathrm{~N}, \mathrm{P} 2 \mathrm{O} 5, \mathrm{~K} 2 \mathrm{O}$ ha $^{-1}$ level of nutrient management followed by 80 : 40 : $40 \mathrm{~kg} \mathrm{~N}, \mathrm{P} 2 \mathrm{O} 5, \mathrm{~K} 2 \mathrm{O} \mathrm{ha}^{-1}$ nutrient dose 
and the least number of filled grain (85) was obtained by F1 NPK nutrient level i.e. 60 : 30 : $30 \mathrm{~kg} \mathrm{~N}, \mathrm{P}_{2} \mathrm{O}_{5}, \mathrm{~K}_{2} \mathrm{O}$ ha $^{-1}$ (Table 2). Filled grain number differentiation due to increase of nutrient dose was about $28.24 \%$ from F1 to F3 levels. Data revealed that increasing level of nitrogen significantly increased number of filled grains panicle ${ }^{-1}$. Similar observation was also reported by Banerjee and Pal (2011) in their findings.

The chaffiness of transplanted rice was significantly influenced by variety in sandy loam soil during kharif season. The hybrid variety PAC 8744 produced the maximum number of chaffy grains panicle ${ }^{-1}(60)$, which is higher over the high yielding variety IET 4786 in the study (Table 2). Chaffy grains variation between two varieties was about $41 \%$. No significant difference was found among different nutrient management on number of chaffy grains panicle ${ }^{-1}$ (Table 2 ).

The grain boldness in terms of one thousand grain weight (test weight) of transplanted rice was significantly influenced by variety and nutrient management. Maximum test weight was obtained from hybrid rice variety, PAC $8744(23.1 \mathrm{~g})$ than the high yielding variety IET 4786 (20.2 g) in the study. Data on the effect of levels of nutrient management towards test weight showed significant variation. The maximum test weight value of $22.4 \mathrm{~g}$ was noted with F3 NPK nutrient level i.e. $100: 50: 50 \mathrm{~kg} \mathrm{ha}^{-1}$ and the least grain weight (20.8 g) was obtained by F1 nutrient NPK dose of $60: 30: 30 \mathrm{~kg} \mathrm{ha}^{-1}$. There was an increasing trend of grain weight of transplanted rice by $8.75 \%$ from $60: 30: 30$ $\mathrm{kg} \mathrm{N}, \mathrm{P}_{2} \mathrm{O}_{5}, \mathrm{~K}_{2} \mathrm{O}$ ha $^{-1}$ and highest at $100: 50$ : $50 \mathrm{~kg} \mathrm{~N}, \mathrm{P}_{2} \mathrm{O}_{5}, \mathrm{~K}_{2} \mathrm{O}$ ha $^{-1}$. Similar observation was also recorded by Banerjee and Pal (2011) and Salem et al., (2011) (Table 2).

Grain yield of hybrid paddy variety PAC 8744 was significantly superior to HYV IET 4786. Hybrid variety PAC 8744 (V1) recorded maximum grain yield of $5.68 \mathrm{t} \mathrm{ha}^{-1}$ which was $2.50 \mathrm{t} \mathrm{ha}^{-1}$ which was $78.41 \%$ more than the HYV IET 4786 during kharif season. Hybrid variety recorded more yield than the HYV mainly due to more number of grains per panicle and thousand grain weights. This was also reported by Maiti and Bhattacharya (2012). Significant difference is found on grain yield among the different nutrient management in sandy loam soils of lower Gangetic plains of West Bengal during kharif season of 2015.

Maximum grain yield $\left(4.59 \mathrm{t} \mathrm{ha}^{-1}\right)$ was obtained from F3 level of nutrient management which is statistically at par with the grain yield obtained from the F2 level of nutrient management. Interaction effect between variety and nutrient management towards grain yield was found significant. The maximum yield in hybrid rice production gave $6.05 \mathrm{t} \mathrm{ha}^{-1}$, was achieved with the application of $100: 50: 50 \mathrm{~kg} \mathrm{~N}, \mathrm{P} 2 \mathrm{O} 5, \mathrm{~K} 2 \mathrm{O}$ $\mathrm{ha}^{-1}$ followed by $5.64 \mathrm{t} \mathrm{ha}^{-1}$ in the treatment 80 : 40 : $40 \mathrm{~kg} \mathrm{~N}, \mathrm{P} 2 \mathrm{O} 5, \mathrm{~K}_{2} \mathrm{O} \mathrm{ha}{ }^{-1}$ (Table 3).

Between the cultivars, PAC 8744 (hybrid rice variety) significantly produced the maximum straw yield (8.50 $\left.\mathrm{tha}^{-1}\right)$ as compared to IET $4786\left(5.27 \mathrm{t} \mathrm{ha}^{-1}\right)$ the straw yield increment was $61.29 \%$ (Table 3). The straw yield increment of hybrid variety PAC 8744 might be attributed to their higher photosynthate accumulation capacity than the high yielding one. With regard to nutrient management, straw yield varied significantly. Among the three nutrient levels, highest straw yield was recorded from $\mathrm{F} 3$ level of nutrient management i.e. 100 : $50: 50 \mathrm{~kg} \mathrm{~N}, \mathrm{P}_{2} \mathrm{O}_{5}$, $\mathrm{K}_{2} \mathrm{O}$ ha $^{-1}$.

There was progressive and significant increase in straw yield with each incremental dose of nutrient applied during the course of investigation (Table 3). This observation also supported the findings of Shivnath-Das et al., 2009, Rakesh-Kumar et al., 2005, Upendra- 
Ram et al., (2004). Data on interaction effect between variety and nutrient management on straw yield showed that both the cultivar recorded highest straw yield at $100: 50: 50$ $\mathrm{kg} \mathrm{N}, \mathrm{P}_{2} \mathrm{O}_{5}, \mathrm{~K}_{2} \mathrm{O} \mathrm{ha}^{-1}$. The harvest index of rice was not significantly influenced by variety and nutrient management. Rice hybrid variety PAC 8744 and IET 4786 recorded higher value of harvest index 0.40 which was at pat with high yielding variety IET 4786 of 0.37. Similarly, nutrient management had failed to register any significant effect on harvest index of rice varieties during kharif season in new alluvial plains of West Bengal (Table 3).

Table.1 Growth attributes as influenced by variety and nutrient management

\begin{tabular}{|c|c|c|c|c|c|c|c|c|c|c|}
\hline Treatment & \multicolumn{2}{|c|}{$\begin{array}{l}\text { Plant height } \\
\text { (cm) at } \\
\text { harvest }\end{array}$} & \multicolumn{2}{|c|}{$\begin{array}{l}\text { Number of } \\
\text { tillers } \mathrm{m}^{-2} \text { at } \\
60 \mathrm{DAT}\end{array}$} & \multicolumn{2}{|c|}{$\begin{array}{c}\text { Leaf area } \\
\text { index at } \\
\text { harvest }\end{array}$} & \multicolumn{2}{|c|}{$\begin{array}{c}\text { Dry matter } \\
\text { accumulation }(\mathrm{g} \\
\left.\mathrm{m}^{-2}\right) \text { at } 90 \mathrm{DAT}\end{array}$} & \multicolumn{2}{|c|}{$\begin{array}{c}\text { Crop growth rate } \\
\left(\mathrm{g} \mathrm{m}^{-2} \text { day }^{-1}\right) 30- \\
60 \text { DAT }\end{array}$} \\
\hline \multicolumn{11}{|l|}{ Variety (V) } \\
\hline$V_{1}$ & \multicolumn{2}{|c|}{111} & \multicolumn{2}{|c|}{476} & \multicolumn{2}{|c|}{3.41} & \multicolumn{2}{|c|}{976.41} & \multicolumn{2}{|c|}{13.54} \\
\hline $\mathbf{V}_{2}$ & \multicolumn{2}{|c|}{94} & \multicolumn{2}{|c|}{390} & \multicolumn{2}{|c|}{2.67} & \multicolumn{2}{|c|}{398.67} & \multicolumn{2}{|c|}{4.79} \\
\hline S. $\operatorname{Em}( \pm)$ & \multicolumn{2}{|c|}{1.02} & \multicolumn{2}{|c|}{21.08} & \multicolumn{2}{|c|}{0.01} & \multicolumn{2}{|c|}{10.20} & \multicolumn{2}{|c|}{0.26} \\
\hline C.D. $(P=0.05)$ & \multicolumn{2}{|c|}{6.69} & \multicolumn{2}{|c|}{128.69} & \multicolumn{2}{|c|}{0.07} & \multicolumn{2}{|c|}{66.81} & \multicolumn{2}{|c|}{1.72} \\
\hline \multicolumn{11}{|c|}{ Nutrient Management (F) @ N, $\mathrm{P}_{2} \mathrm{O}_{5}, \mathrm{~K}_{2} \mathrm{O} \mathrm{kg} \mathrm{ha}^{-1}$} \\
\hline $\mathbf{F}_{1}$ & & 03 & & & 2. & & 665 & & & \\
\hline $\mathbf{F}_{2}$ & & 02 & & & 2. & & 685 & & & \\
\hline $\mathbf{F}_{\mathbf{3}}$ & & 03 & & & 3. & & 710 & & & \\
\hline S. Em $( \pm)$ & & 37 & & & 0 . & & 10. & & & \\
\hline C.D. $(P=0.0$ & & IS & & & 0 . & & 33. & & & \\
\hline Interaction $b$ & between V & riety a & d Nutri & nt level & $(\mathbf{V} \times \mathbf{F})$ & & & & & \\
\hline $\mathbf{V}_{1} \mathbf{F}_{1}$ & 1 & & & & & & 94 & & & \\
\hline $\mathbf{V}_{1} \mathbf{F}_{2}$ & 1 & & & & & & 97 & & & \\
\hline $\mathbf{V}_{1} \mathbf{F}_{3}$ & 1 & & & & & & 100 & & & \\
\hline $\mathbf{V}_{2} \mathbf{F}_{1}$ & 9 & & & & & & 38 & & & \\
\hline $\mathbf{V}_{2} \mathbf{F}_{2}$ & 9 & & & & & & 39 & & & \\
\hline $\mathbf{V}_{2} \mathbf{F}_{3}$ & 9 & & & & & & 42 & & & \\
\hline & $\mathrm{V} \times \mathrm{F}$ & $\mathrm{F} \times \mathrm{V}$ & $\mathrm{V} \times \mathrm{N}$ & $\mathrm{N} \times \mathrm{V}$ & $\mathrm{V} \times \mathrm{N}$ & $\mathrm{N} \times \mathrm{V}$ & $\mathrm{V} \times \mathrm{N}$ & $\mathrm{N} \times \mathrm{V}$ & $V \times F$ & $\mathrm{~F} \times \mathrm{V}$ \\
\hline S. Em ( $( \pm)$ & 1.77 & 1.88 & 36.52 & 25.73 & 0.02 & 0.08 & 17.67 & 15.62 & 0.45 & 0.53 \\
\hline $\begin{array}{c}\text { C.D. } \\
(P=0.05)\end{array}$ & NS & NS & NS & NS & NS & NS & NS & NS & NS & NS \\
\hline $\begin{array}{l}\text { V1 } \\
\text { V2 }\end{array}$ & $\begin{array}{l}\text { PAC } 8744 \\
\text { IET } 4786\end{array}$ & $\begin{array}{l}\text { F1 } \\
\text { F2 } \\
\text { F3 }\end{array}$ & $\begin{array}{l}60: 3 \\
80: 4 \\
100:\end{array}$ & $\begin{array}{l}: 30 \mathrm{~kg} \mathrm{~N} \\
: 40 \mathrm{~kg} \mathrm{~N} \\
: 50 \mathrm{~kg}\end{array}$ & $\begin{array}{l}\mathrm{P} 2 \mathrm{O} 5, \mathrm{~K} \\
\mathrm{P} 2 \mathrm{O} 5, \mathrm{~K} \\
\mathrm{P} 2 \mathrm{O} 5, \mathrm{~K}\end{array}$ & $\begin{array}{l}\text { ha-1 } \\
\text { ha-1 } \\
\text { O ha-1 }\end{array}$ & & & & \\
\hline
\end{tabular}


Table.2 Yield components as influenced by variety and nutrient management

\begin{tabular}{|c|c|c|c|c|c|c|c|c|c|c|}
\hline Treatment & \multicolumn{2}{|c|}{$\begin{array}{c}\text { Panicle length } \\
\text { (cm) }\end{array}$} & \multicolumn{2}{|c|}{\begin{tabular}{c|} 
No. of \\
panicles $\mathbf{m}^{-2}$
\end{tabular}} & \multicolumn{2}{|c|}{$\begin{array}{c}\text { No of filled grains } \\
\text { panicle }^{-1}\end{array}$} & \multicolumn{2}{|c|}{$\begin{array}{c}\text { Chaffy grains } \\
(\%)\end{array}$} & \multicolumn{2}{|c|}{$\begin{array}{l}1000 \text { grain } \\
\text { weight }(g)\end{array}$} \\
\hline \multicolumn{11}{|l|}{ Variety (V) } \\
\hline$\dot{V}_{1}$ & \multicolumn{2}{|c|}{24.2} & \multicolumn{2}{|c|}{473} & \multicolumn{2}{|c|}{116} & \multicolumn{2}{|c|}{$60(35)$} & \multicolumn{2}{|c|}{23.1} \\
\hline $\mathbf{V}_{2}$ & \multicolumn{2}{|c|}{22.3} & \multicolumn{2}{|c|}{334} & \multicolumn{2}{|c|}{73} & \multicolumn{2}{|c|}{$50(41)$} & \multicolumn{2}{|c|}{20.2} \\
\hline S. Em $( \pm)$ & \multicolumn{2}{|c|}{0.37} & \multicolumn{2}{|c|}{16.19} & \multicolumn{2}{|c|}{0.85} & \multicolumn{2}{|c|}{0.701} & \multicolumn{2}{|c|}{0.35} \\
\hline $\begin{array}{c}\text { C.D. } \\
(\mathbf{P}=\mathbf{0 . 0 5})\end{array}$ & \multicolumn{2}{|c|}{ NS } & \multicolumn{2}{|c|}{100.37} & \multicolumn{2}{|c|}{5.54} & \multicolumn{2}{|c|}{4.590} & \multicolumn{2}{|c|}{2.27} \\
\hline \multicolumn{11}{|c|}{ Nutrient Management (F) @ N, $\mathrm{P}_{2} \mathrm{O}_{5}, \mathrm{~K}_{2} \mathrm{O} \mathrm{kg} \mathrm{ha}^{-1}$} \\
\hline $\mathbf{F}_{1}$ & \multicolumn{2}{|c|}{21.8} & \multicolumn{2}{|c|}{307} & \multicolumn{2}{|c|}{85} & \multicolumn{2}{|c|}{$56(40)$} & \multicolumn{2}{|c|}{20.8} \\
\hline $\mathbf{F}_{2}$ & & & & & & & & & & \\
\hline $\mathbf{F}_{\mathbf{3}}$ & & & & & & & & & & \\
\hline S. Em ( $( \pm)$ & & & & & & & & & & \\
\hline $\begin{array}{c}\text { C.D. } \\
(\mathbf{P}=0.05)\end{array}$ & & & & & & & & & & \\
\hline Interaction $\mathrm{t}$ & tween & riety a & d Nutri & level & $(\mathbf{V} \times \mathbf{F})$ & & & & & \\
\hline $\mathbf{V}_{1} \mathbf{F}_{1}$ & & & & & & & & & & \\
\hline $\mathbf{V}_{1} \mathbf{F}_{2}$ & & & & & & & & & & \\
\hline $\mathbf{V}_{1} \mathbf{F}_{3}$ & & & & & & & & & & \\
\hline $\mathbf{V}_{2} \mathbf{F}_{1}$ & & & & & & & & & & \\
\hline $\mathbf{V}_{2} \mathbf{F}_{2}$ & & & & & & & & & & \\
\hline $\mathbf{V}_{2} \mathbf{F}_{3}$ & & & & & & & & & & \\
\hline & $\mathrm{V} \times \mathrm{F}$ & $\mathrm{V} \times \mathrm{F}$ & $\mathrm{V} \times \mathrm{F}$ & $\mathrm{V} \times \mathrm{F}$ & $\mathrm{V} \times \mathrm{F}$ & $\mathrm{V} \times \mathrm{F}$ & $\mathrm{V} \times \mathrm{F}$ & $\mathrm{V} \times \mathrm{F}$ & $\mathrm{V} \times \mathrm{F}$ & $\mathrm{V} \times \mathrm{F}$ \\
\hline S. Em ( $( \pm)$ & 0.65 & 0.47 & 28.05 & 21.02 & 1.47 & 1.49 & 1.21 & 3.40 & 0.60 & 0.47 \\
\hline C.D. (0.05) & NS & NS & NS & NS & NS & NS & 14.06 & 11.73 & NS & NS \\
\hline $\begin{array}{ll}\text { V1 } & \text { P } \\
\text { V2 } & \text { II }\end{array}$ & $\begin{array}{l}C 8744 \\
4786\end{array}$ & $\begin{array}{l}\text { F1 } \\
\text { F2 } \\
\text { F3 }\end{array}$ & $\begin{array}{l}60: 30: \\
80: 40: \\
100: 50\end{array}$ & $\begin{array}{l}\mathrm{kg} \mathrm{N}, \mathrm{P} \\
\mathrm{kg} \mathrm{N}, \mathrm{P} \\
\mathrm{kg} \mathrm{N}\end{array}$ & $\begin{array}{l}2 \mathrm{O} 5, \mathrm{~K} 2 \mathrm{O} \text { ha } \\
2 \mathrm{O} 5, \mathrm{~K} 2 \mathrm{O} \text { ha } \\
\mathrm{P} 2 \mathrm{O} 5, \mathrm{~K} 2 \mathrm{O}\end{array}$ & & & & & \\
\hline
\end{tabular}


Table.3 Yield as influenced by variety and nutrient management

\begin{tabular}{|c|c|c|c|c|c|c|}
\hline Treatment & \multicolumn{2}{|c|}{ Grain yield (t ha') } & \multicolumn{2}{|c|}{ Straw yield $\left(\mathrm{t} \mathrm{ha}^{-1}\right)$} & Harv & $\operatorname{lex}(\%)$ \\
\hline \multicolumn{7}{|l|}{ Variety (V) } \\
\hline $\mathbf{V}_{1}$ & \multicolumn{2}{|c|}{5.68} & \multicolumn{2}{|c|}{8.50} & \multicolumn{2}{|c|}{0.40} \\
\hline $\mathbf{V}_{2}$ & \multicolumn{2}{|c|}{3.18} & \multicolumn{2}{|c|}{5.27} & \multicolumn{2}{|c|}{0.37} \\
\hline S. $\operatorname{Em}( \pm)$ & \multicolumn{2}{|c|}{0.112} & \multicolumn{2}{|c|}{0.264} & \multicolumn{2}{|c|}{0.004} \\
\hline C.D. $(P=0.05)$ & \multicolumn{2}{|c|}{0.731} & \multicolumn{2}{|c|}{1.729} & \multicolumn{2}{|c|}{ NS } \\
\hline \multicolumn{7}{|c|}{ Nutrient Management (F) @ N, $\mathbf{P}_{2} \mathrm{O}_{5}, \mathrm{~K}_{2} \mathrm{O} \mathrm{kg} \mathrm{ha}^{-1}$} \\
\hline $\mathbf{F}_{1}$ & \multicolumn{2}{|c|}{4.22} & \multicolumn{2}{|c|}{6.30} & \multicolumn{2}{|c|}{0.39} \\
\hline $\mathbf{F}_{2}$ & \multicolumn{2}{|c|}{4.48} & \multicolumn{2}{|c|}{6.89} & \multicolumn{2}{|c|}{0.39} \\
\hline $\mathbf{F}_{3}$ & \multicolumn{2}{|c|}{4.59} & \multicolumn{2}{|c|}{7.47} & \multicolumn{2}{|c|}{0.37} \\
\hline S. Em $( \pm)$ & \multicolumn{2}{|c|}{0.06} & \multicolumn{2}{|c|}{0.13} & \multicolumn{2}{|c|}{0.007} \\
\hline C.D. $(P=0.05)$ & \multicolumn{2}{|c|}{0.21} & \multicolumn{2}{|c|}{0.43} & \multicolumn{2}{|c|}{ NS } \\
\hline \multicolumn{7}{|c|}{ Interaction between Variety and Nutrient level $(\mathbf{V} \times \mathbf{F})$} \\
\hline $\mathbf{V}_{1} \mathbf{F}_{1}$ & \multicolumn{2}{|c|}{5.35} & \multicolumn{2}{|c|}{7.59} & & \\
\hline $\mathbf{V}_{1} \mathbf{F}_{2}$ & & & & & & \\
\hline $\mathbf{V}_{\mathbf{1}} \mathbf{F}_{3}$ & & & & & & \\
\hline $\mathbf{V}_{2} \mathbf{F}_{1}$ & & & & & & \\
\hline $\mathbf{V}_{2} \mathbf{F}_{2}$ & & & & & & \\
\hline $\mathbf{V}_{2} \mathbf{F}_{3}$ & & & & & & \\
\hline & $\mathrm{V} \times \mathrm{F}$ & $\mathrm{F} \times \mathrm{V}$ & $\mathrm{V} \times \mathrm{F}$ & $\mathrm{F} \times \mathrm{V}$ & $\mathrm{V} \times \mathrm{F}$ & $\mathrm{F} \times \mathrm{V}$ \\
\hline S. $\operatorname{Em}( \pm)$ & 0.193 & 0.135 & 0.457 & 0.304 & 0.007 & 0.009 \\
\hline C.D. $(P=0.05)$ & 0.516 & 0.746 & 1.006 & 1.749 & NS & NS \\
\hline PAC 8744 & F1 & $0: 30: 30 \mathrm{k}$ & $\mathrm{P} 2 \mathrm{O} 5, \mathrm{~K} 2$ & & & \\
\hline V2 IET 4786 & $\begin{array}{l}\mathrm{F} 2 \\
\mathrm{~F} 3\end{array}$ & $\begin{array}{l}0: 40: 40 \mathrm{k} \\
00: 50: 50\end{array}$ & $\begin{array}{l}\mathrm{P} 2 \mathrm{O} 5, \mathrm{~K} 2 \\
\mathrm{P} 2 \mathrm{O} 5, \mathrm{~K}\end{array}$ & & & \\
\hline
\end{tabular}

Thus it may be concluded that hybrid rice variety PAC 8744 with higher plant height, higher LAI, higher dry matter accumulation, higher number of filled grains panicle ${ }^{-1}$, test weight as well as higher grain yield, straw yield appeared to be better cultivar.

So, it is advantageous to grow hybrid rice variety supplied with $100: 50: 50 \mathrm{~kg} \mathrm{~N}$, P2O5, K2O ha ${ }^{-1}$ nutrient dose while cultivation of high yielding variety can be recommended with $80: 40: 40 \mathrm{~kg} \mathrm{~N}, \mathrm{P} 2 \mathrm{O} 5$, $\mathrm{K} 2 \mathrm{O} \mathrm{ha}{ }^{-1}$ nutrient level during kharif season.

\section{References}

Anonymous. 2000. Agricultural Statistics at a Glance. Directorate of Economics and Statistics, Department of Agriculture, Government of India, New Delhi. Pp 20-25.

Banerjee, H. and Pal, S. 2009. Integrated nutrient management for rice rice cropping system. Oryza. 46(32-36).

Blanco, L.C., Casal, C., Akita, S. and Virmani, S.S. 1990. Biomass grain yield and harvest index of F1 hybrids and inbreds. International Rice Research 
Newslatter 15(2): 9-10.

Gomez, K.A. and Gomez, A. A. 1984. Statistical procedures for agricultural research (2 ed.). John wiley and sons, NewYork, Pp. 680.

Ishizuka, Y. and Tanaka, A. 1963. Studies on nutrio-physiology of the rice plant. Yokendo, Tokyo. Pp. 307.

Maiti, P.K. and Bhattacharya, B. 2012. Response of hybrid rice (Oryza sativa) to nitrogen application in dry (boro) season. Journal of Interacademicia. 16(1): 65-79.

Matshusima, S. 1957. Analysis of development factors determining yield and yield prediction in low land rice. Bull. Nat. Inst. Agr. Sci. Japan Ser A. 5: 1-271.

Murthy, E.N.S., Hittalamani, S. and Vdeyking, M. 1991. Association analysis among yield and some physiological fruits in rice Oryza. 28(2): 257-260.

Salem, A.K.M., ElKhoby, W.M., AbouKhalifa, A.B. and Ceesay, M. 2011. Effect of Nitrogen fertilizer and seedling age on inbred and hybrid rice varieties. American Eurasian Journal of Agricultural and EnvironmentalSciences. 11(5): 640-646.

Singh, R.B. and Virmani, S.S. 1990. Recent progress in the technology and development of hybrid rice in Asia. Int. Rice. Comm. Newsl. 39: 133-145.

Sitaramaiah, K.V., Madhuri, J. and Reddy, N.S. 1998. Physiological efficiency of rice hybrids. Int. Rice Res. Notes. 23(2): 32-33.

Sitaramaiah, K.V., Madhuri, J. and Reddy, N.S. 1998. Physiological efficiency of rice hybrids. Int. Rice Res. Notes. 23(2): 32-33.

Song, X.F., Agata, W. and Kawamitsu, Y. 1990. Studies on dry matter and grain production of F1 hybrid rice on China. 11. Characteristics of grain production Japanica. J. Crop Science, 59: 29-33.

Thakur, D.S. and Patel, S.R. 1999. Growth and sink potential of rice as influenced by split application of nitrogen with and without FYM in inceptisols of eastern part of central peninsular India. Oryza. 36(3): 280-282.

Virmani, S.S., Aquino, R.C. and Khus, G.S. 1982. Heterosis breeding in rice (Oryza sativa) Theoretical Application of Genetics, 63: 373-380.

Yoshida, S. 1981. Fundamental of Rice Crop Science. International Rice Research Institute, Los Baños, Laguna, Philippines. Pp. 269

\section{How to cite this article:}

Poulomi Nandy, Subhendu Bikash Goswami and Sanjib Kumar Das. 2020. Effect of Differential Nutrient Levels on the Performance of Paddy Hybrid Variety during Kharif Season. Int.J.Curr.Microbiol.App.Sci. 9(04): 884-892.

doi: https://doi.org/10.20546/ijcmas.2020.904.106 